\title{
PENGARUH PEMBELAJARAN ORGANISASI DAN MOTIVASI KERJA TERHADAP KINERJAKARYAWAN KOPERASI SYARIAH
}

\author{
Muchni Marlikan \\ Sekolah Tinggi Ilmu Ekonomi Indonesia Malang \\ E-mail :mughnimarlikanstiei@yahoo.co.id
}

\begin{abstract}
This research is carried out in Sharia Cooperation. The aims is to study and analyses the influence of learning organization and workers' motivation on workers' performance at Sharia Cooperation in Malang Raya. Unit analyses in this research are 33 Co-Operation unit which is spread over Malang Town, Malang Sub-Province, and Batu Town. Research Population are 170 workers who works as employees of Moslem Law Co-Operation (BMT). Sample size is selected by using proportional technique or sample balance (118 workers). Data are analysis by using SEM (Structural Equation Modeling) and use the program of software of computer of data processing AMOS (Analysis Of Moment Structure) v.4.0. The Result of research indicates that 1). The Learning Organization has an positive and significant effect to employees' performance, it is proved by the standardized value $(0,526)$ and p-value $(0,002)$. The Work Motivation of employee have an positive and significant effect to employees' performance too, and it is proved by the standardized value $(0,391)$ and p-value $(0,00)$. The research conclusion is still needed the development of co-operation science in relation with adopting economics theory and co-operation management with the public vision (conventional) and also Moslem Law Islam. While practical implication from this research is the improvement of human resources as an effective strength in facing the competitiveness of Moslem Law Co-Operation (BMT) as a whole.
\end{abstract}

Keywords: learning organizational, work motivate, employees performance

\section{PENDAHULUAN}

Sistem ekonomi negara-negara Islam sangat membutuhkan suatu sistem lebih baik yang mampu memberikan semua elemen berperan dalam rangka mencapai kesejahteraan dan kebahagiaan umat manusia seutuhnya. Sebagai sumber dasar tindakan manusia (ibadah) seperti diungkapkan dalam al-Qur'an "Hai orang-orang yang beriman!, Patuhilah seruan Allah dan seruan Rasul apabila Rasul menyeru kamu kepada suatu yang memberi kehidupan kepada kamu (rohani dan jasmani). Dan ketahuilah bahwa sesungguhnya Allah memberi batas antara manusia dan hatinya dan sesungguhnya kepada-Nyalah kamu akan dikumpulkan". (QS. al-Anfaal (8):24 ).

Alternatif yang diberikan Islam dalam rangka menghapuskan riba dalam praktek mu'amalah yang dilakukan manusia. Sistem lembaga keuangan Islam di dalamnya menyangkut penghimpunan dana melalui tabungan mudharabah, deposito musyarakah, giro wadiah, kemudian disalurkan melalui pembiayaan bagi hasil, prinsip jual beli (Bai' Bitsaman Ajil dan Murabahah) serta prinsip sewa (ijarah/Bai' Ta'jri). Dari kedua jalan diatas secara sistematik diatur dan dikelola melalui kelembagaan yang disebut Baitul Maal wa Tamwil yang disingkat BMT (Ensiklopedi Ekonomi Islam, 2008).

BMT lahir di tengah-tengah masyarakat bertujuan memberikan solusi pendanaan yang mudah dan cepat, mengacu pada prinsip syariah, dan terhindar dari jerat rentenir. Baitul Maal wa Tamwil yang disingkat BMT sebagai lembaga keuangan mikro berbasis syariah muncul dan mencoba menawarkan solusi bagi masyarakat yang membutuhkan pendanaan. BMT dapat dikaitkan sebagai suatu lembaga swadaya masyarakat yang bergerak di bidang keuangan, lembaga ini tidak hanya bergerak dalam pengelolaan modal uang saja, tetapi BMT juga bergerak dalam pengumpulan zakat, infaq, dan shodaqah (Sumiyanto A, 2008).

Baitul Maal wa Tamwil (BMT) terdiri dari dua istilah, yaitu Baitul Maal dan Baitul Tamwil. Baitul 
Maal lebih mengarah pada usaha-usaha non profit pengumpulan dana seperti zakat, infaq dan shodaqah dan penyaluran dana kepada yang berhak sebagai wujud distribusi pendapatan dan bertujuan dalam mengatasi kemiskinan dan kesenjangan ekonomi. Sedangkan Baitul Tamwil sebagai usaha pengumpulan dan penyaluran dana komersial profit untuk menciptakan nilai tambah baru dan mendorong pertumbuhan ekonomi.

Secara kelembagaan BMT didampingi atau didukung Pusat Inkubasi Bisnis Usaha Kecil (PINBUK) yang mengemban misi lebih luas, yakni menetaskan usaha kecil. Dalam prakteknya, PINBUK menetaskan BMT, dan pada gilirannya BMT menetaskan usaha kecil (Rahardjo, M.D, 1999). Menurut Sumiyanto (2008), legal formal BMT di Indonesia berbadan hukum koperasi syariah. Sehingga seluruh gerak dan langkahnya sejalan dengan ketentuan tentang perkoperasian selain juga dengan konsep-konsep syariah Islam. Oleh sebab itu ketentuan perundang-undangan terkait dengan koperasi adalah Undang-Undang Nomor 25 tahun 1992 tentang Perkoperasian.

Proses pembelajaran menemukan adanya kemauan untuk menanggapi perubahan (Hartanto, 1995), ini menunjukkan adanya semangat untuk terus memperbarui diri. Senge (1990) sebagai pencetus organisasi pembelajaran, yang di-maksud pembelajaran organisasi adalah, organisasi yang dapat memotivasi orang-orang di dalamnya secara berkelanjutan, meningkatkan kapasitas mencapai apa yang dicita-citakan, mengembangkan pola pikir baru, mengutarakan aspirasi kolektif secara bebas dan para anggota organisasi belajar bersama berkelanjutan.

Peran motivasi dalam kinerja pada organisasi sangatlah penting. Pattigrew (1991) dalam Walton (1999) mengemukakan bahwa motivasi merupakan faktor penting untuk kinerja perusahaan. Di dalam pencapaian kinerja karyawan, motivasi mempunyai pengaruh yang signifikan seperti dikemukakan Nimran (1996) yang mengatakan motivasi sebagai keadaan di mana usaha dan kemauan keras seseorang diarahkan kepada pencapaian hasil-hasil tertentu.

Kinerja karyawan sangat penting dilakukan penilaian atau evaluasi seperti dikatakan Mangku-prawira (2004) penilaian kinerja sebagai proses yang dilakukan perusahaan dalam mengevaluasi kinerja pekerjaan seseorang. Penilaian kinerja meliputi dimensi kinerja karyawan dan akuntabilitas. Dalam dunia kompetitif global, perusahaan membutuhkan kinerja karyawan yang tinggi. Pada waktu yang sama para karyawan membutuhkan umpan balik tentang kinerja mereka sebagai petunjuk untuk mempersiapkan perilaku masa depan.

Sinn (2006) dalam Meldona (2009) mengemukakan bahwa kinerja karyawan merupakan persoalan krusial dalam hubungan antara atasan dan bawahan pada suatu organisasi. Allah SWT mendorong untuk memberikan insentif bagi orang yang mampu menunjukkan kinerja optimal (baik), disarikan dari QS al-Nahl 16:97. Maka penulis berkeinginan meneliti tentang pengaruh pembelajaran organisasi dan motivasi kerja terhadap kinerja karyawan Koperasi Syariah (BMT) di Malang Raya. Sehingga akan memberikan masukan dan tambahan ilmu pengetahuan bagi pihak terkait pengelolaan dan pengembangan Koperasi Syariah (BMT) khususnya dan pemerhati ekonomi Islam umumnya.

Dalam penelitian ini setelah diuraikan mengenai Koperasi Syariah (BMT), beserta variabel-variabel yang melingkupi manajemen pengelolaannya, maka di bawah ini diidentifikasi beberapa masalah kausalitas yang membutuhkan kajian lebih mendalam, yakni antara lain : (1) Apakah pembelajaran organisasi berpengaruh terhadap kinerja karyawan Koperasi Syariah (BMT)? (2) Apakah motivasi kerja berpengaruh terhadap kinerja karyawan Koperasi Syariah (BMT)? (3) Apakah pembelajaran organisasi dan motivasi kerja berpengaruh terhadap kinerja karyawan Koperasi Syariah (BMT)?

Tujuan dari penelitian ini adalah untuk mengetahui sejauh mana pengaruh variabel pembelajaran organisasi dan motivasi kerja terhadap kinerja karyawan pada Koperasi Syariah (BMT) di Malang Raya.

\section{METODE PENELITIAN}

Penelitian ini merupakan penelitian kuantitatif dengan rancangan penelitian survey yang menggunakan Cross Sectional Survey. Penelitian ini mengambil Malang Raya sebagai lokasi penelitian yang terbagi dalam tiga wilayah, yaitu: Kota Malang, Kabupaten Malang, dan Kota Batu. Populasi dari penelitian ini adalah pengelola Koperasi Syariah (BMT) yang terdiri dari manajemen dan karyawan pada lokasi penelitian. Sampel yang diperoleh dari populasi penelitian ini adalah sebanyak 118 orang yang selanjutnya dijadikan sebagai responden dalam penelitian ini.

Desain metodologi pada penelitian ini adalah sebagai berikut

a. Berdasarkan data yang dianalisis dalam penelitian 
ini dapat dikategorikan dalam jenis penelitian observasional, di mana peneliti berupaya untuk melakukan observasi terhadap fenomena tanpa melakukan intervensi dan manipulasi atas fenomena yang diamati.

b. Berdasarkan model analisa data, penelitian ini dikategorikan dalam penelitian analitis. Teknik ini dilakukan untuk menganalisis unit data yang muncul dari fenomena, maka pengambilan sampel untuk digeneralisasi dalam populasi dan sampel.

c. Penelitian ini disebut penelitian penjelasan (Ekplanatory Research) karena tujuannya untuk menjelaskan hubungan pengaruh variabel melalui pengujian hipotesis, juga merupakan penelitian korelasional yaitu penelitian yang bertujuan mengetahui suatu variabel berkaitan dengan satu atau lebih variabel lainnya.

Teknik analisis data kuantitatif dalam penelitian ini adalah dengan menggunakan Structural
Equation Modelling (SEM), yang menggunakan program komputer AMOS 4.0. Keunggulan SEM karena kemam-puannya menampilkan sebuah model komprehensif bersamaan dengan kemampuannya mengkonfirmasi dimensi-dimensi dari sebuah konstruk atau faktor serta kemampuannya untuk mengukur pengaruh hubungan secara teoritis.

\section{HASIL PENELITIAN DAN PEMBAHASAN}

Penelitian ini mengambil lokasi penelitian pada tiga wilayah administratif pemerintahan daerah, yaitu Kota Malang, Kabupaten Malang, dan Kota Batu yang terletak di Provinsi Jawa Timur. Populasi dalam penelitian ini adalah seluruh karyawan koperasi syariah (BMT) yang ada di Malang Raya yang berhubungan dengan obyek penelitian, yaitu pembelajaran organisasi, dan motivasi serta kinerja karyawan. Sedangkan unit analisis atau sampel yang diambil dalam penelitian ini adalah karyawan koperasi syariah yang bisa dilihat dalam tabel 2 dibawah ini :

Tabel 2. Jumlah Karyawan Koperasi Syariah Malang Raya

\begin{tabular}{llc}
\hline No & \multicolumn{1}{c}{ Lokasi } & Jumlah Karyawan \\
\hline 1 & Kota Malang & 112 Orang \\
2 & Kabupaten Malang & 48 Orang \\
3 & Kota Batu & 10 Orang \\
\hline Jumlah & 170 Orang \\
\hline
\end{tabular}

Sehingga populasi dalam penelitian ini aalah seluruh karyawan staf pelaksana sampai manajer sebanyak 170 orang dari 33 koperasi syariah. Untuk menentukan sampel pada penelitian ini menggunakan metode proportional sample, dimana sampel yang diperoleh adalah representasi wakili dari populasi penelitian tersebut dengan menggunakan rumus:

$$
\begin{aligned}
\mathrm{S} & =\frac{\mathrm{X} 2 \mathrm{NP}(1-\mathrm{P})}{\mathrm{d} 2(\mathrm{~N}-1)+\mathrm{X} 2 \mathrm{P}(1-\mathrm{P})} \\
\mathrm{S} & =\frac{3,841 \times 170 \times 0,5(1-0,5)}{0,05(170-1)+3,841 \times 0,5(1-0,5)} \\
& =\frac{163,2425}{1,38275}=118,056(=118 \text { dibulatkan })
\end{aligned}
$$

Uji validitas dilakukan dengan mengukur korelasi product moment dengan skor masing-masing item dengan skor. Pada tabel 3 di bawah ini, diketahui bahwa untuk variabel pembelajaran organisasi (X1) dari 9 butir pertanyaan, semua pernyataan dianggap valid dan memenuhi syarat untuk dipakai pengumpulan data.
Selanjutnya pada tabel 4 di bawah ini menunjukkan uji validitas atas butir-butir pertanyaan untuk kuisiner pengumpulan data variabel motivasi kerja sebagai berikut.

Untuk menguji reliabilitas dapat memakai koefesien Alpha cronbach. Bila koefesien Alpha Cronbach lebih besar atau sama dengan 0,6 maka instrumen tersebut sudah dianggap reliabel. Skala ukur dinyatakan reliabel jika selalu mendapat hasil yang tetap sama dari gejala pengukuran yang tidak berubah. Pada tabel 5, diketahui bahwa instrumen penelitian dari empat variabel dianggap reliabel dan memenuhi syarat dalam pengumpulan data.

Setelah dilakukan analisis untuk menentukan validitas, reliabilitas, signifikasi, dan linieritas variabel dan beberapa dampak yang timbul karena proses pengaruh antar variabel yang sedang diteliti, maka selanjutnya untuk mengembangkan pembahasan analisis pada penelitian ini. 
60 Jurnal Manajemen Bisnis • Volume 1 No. 01 • Edisi April 2011

\begin{tabular}{lccc}
\hline Variabel & Item & $\mathbf{r}$ & Keterangan \\
\hline Pembelajaran & X1.1.1 & $0,903^{* *}$ & Valid \\
Organisasi (X1) & X1.1.2 & $0,894^{* *}$ & Valid \\
& X1.1.3 & $0,904^{* *}$ & Valid \\
& X1.1.4 & $0,378^{* *}$ & Valid \\
& X1.2.1 & $0,787^{* *}$ & Valid \\
& X1.2.2 & $0,859^{* *}$ & Valid \\
& X1.2.3 & $0,870^{* *}$ & Valid \\
& X1.3.1 & $0,721^{* *}$ & Valid \\
& X1.3.2 & $0,649^{* *}$ & Valid \\
& X1.3.3 & $0,617^{* *}$ & Valid \\
& X1.3.4 & $0,640^{* *}$ & Valid \\
\hline
\end{tabular}

Taraf Signifikan 0,01.

\begin{tabular}{llll}
\hline Variabel & Item & r & Keterangan \\
\hline Motivasi (X2) & X2.1.1 & $0,677^{* *}$ & Valid \\
& X2.1.2 & $0,721^{* *}$ & Valid \\
& X2.3.1 & $0,751^{* *}$ & Valid \\
& X2.2.2 & $0,730^{* *}$ & Valid \\
& X2.2.3 & $0,792^{* *}$ & Valid \\
X2.3.1 & $0,798^{* *}$ & Valid \\
X2.3.2 & $0,756^{* *}$ & Valid \\
X2.3.3 & $0,767^{* *}$ & Valid \\
& X2.3.4 & $0,788^{* *}$ & Valid \\
X2.4.1 & $0,705^{* *}$ & Valid \\
X2.4.2 & $0,618^{* *}$ & Valid \\
X2.4.3 & $0,720^{* *}$ & Valid \\
X2.4.4 & $0,684^{* *}$ & Valid \\
X2.5.1 & $0,660^{* *}$ & Valid \\
X2.5.2 & $0,688^{* *}$ & Valid \\
X2.5.3 & $0,778^{* *}$ & Valid \\
X2.5.4 & $0,705^{* *}$ & Valid \\
X2.6.1 & $0,658^{* *}$ & Valid \\
X2.6.2 & $0,738^{* *}$ & Valid \\
X2.6.3 & $0,756^{* *}$ & Valid \\
X2.6.4 & $0,686^{* *}$ & Valid \\
X2.7.1 & $0,812^{* *}$ & Valid \\
X2.7.2 & $0,859^{* *}$ & Valid \\
X2.7.3 & $0,772^{* *}$ & Valid \\
X2.8.1 & $0,773^{* *}$ & Valid \\
X2.8.2 & $0,790^{* *}$ & Valid \\
X2.8.3 & $0,759^{* *}$ & Valid \\
X2.9.1 & $0,594^{* *}$ & Valid \\
X2.9.2 & $0,598^{* *}$ & Valid \\
X2.9.3 & $0,613^{* *}$ & Valid \\
X2.9.4 & $0,622^{* *}$ & Valid \\
\hline
\end{tabular}

Taraf Signifikan 0,01.

Sumber: Diolah tahun 2010 
Tabel 5. Uji Reliabilitas Variabel

\begin{tabular}{lll}
\hline Variabel & $\mathrm{r}$ & Keterangan \\
\hline Pembelajaran Organisasi (X1) & $0,9436^{* *}$ & Reliabel \\
Motivasi Kerja (X3) & $0,9704^{* *}$ & Reliabel \\
Kinerja Karyawan(Y) & $0,9646^{* *}$ & Reliabel \\
\hline
\end{tabular}

** Taraf Signifikan 0,01.

Proses pembelajaran organisasi terbangun dalam proses struktural maupun non-struktural, baik sistematis maupun non-sistematis.Pembelajaran organisasi dalam penelitian ini terbentuk atas tiga faktor pendukungnya, yaitu Pendidikan dan Latihan,
Mentoring (Pembimbingan), dan pengalaman di lapangan. Ketiga faktor ini memiliki pengaruh terhadap pembelajaran organisasi yang masingmasing ditunjukkan pada Tabel 6 .

Tabel 6. Variabel Pembelajaran Organisasi dan Faktor Pembentuknya

\begin{tabular}{lllll}
\hline Indikator & Standardize & Estimate & $\mathrm{P}$ & Keterangan \\
\hline $\mathrm{X} 1.1$ & 0,708 & 1 & 0 & Valid \\
$\mathrm{X} 1.2$ & 0,929 & 1,482 & 0 & Valid \\
$\mathrm{X} 1.3$ & 0,930 & 2,292 & 0 & Valid \\
\hline
\end{tabular}

Sumber : Data diolah

Sehingga secara statistik dapat dikatakan pengaruh faktor pendukung pada variabel Pembelajaran Organisasi (X1) adalah; Faktor Pendidikan dan Latihan 0,708; Faktor Pembimbingan (Mentoring) sebesar 0,929; dan Pengalaman di lapangan sebesar 0,930. Sehiingga dapat dikatakan bahwa faktor pengalaman di lapangan memiliki pengaruh lebih besar dari pada lainnya beserta pembimbingan yang memiliki selisih 0,001; dan diikuti oleh Pendidikan dan Latihan. Pengaruh ketiga faktor pembentuknya bersifat positif dan valid terhadap variabel pembelajaran organisasi secara langsung yang ditunjukkan dengan nilai statistik hasil dari analisis regresi di atas.
Motivasi memiliki faktor pendukung yang membentuknya antara lain : 1) Kebutuhan sendiri dan keluarga (X2.1); 2) Kebutuhan ibadah (X2.2); 3) Mengembangkan diri (X2.3); 4) Penempatan karyawan sesuai kemampuan/ keahlian (X2.4); 5) Kebutuhan partisipasi time (X2.5); 6) Adanya pengakuan (X2.6); 7) Reward (X2.7); 8) Hukuman (X2.8); dan 9) Perasaan tenang karyawan (X2.9). Dimana secara statistik sembilan faktor pendukung variabel Motivasi memiliki pengaruh positif dan besaran nilai yang dihasilkan dari proses komputasi dikatakan valid dapat dilihat pada Tabel 7.

Tabel 7. Variabel Motivasi dan Faktor Pembentuknya

\begin{tabular}{|c|c|c|c|c|}
\hline Indikator & Standardize & Estimate & $\mathrm{P}$ & Keterangan \\
\hline$\overline{\mathrm{X} 3.1}$ & 0,701 & 0,965 & 0 & Valid \\
\hline $\mathrm{X} 3.2$ & 0,786 & 1 & 0 & Valid \\
\hline X3.3 & 0,823 & 0,961 & 0 & Valid \\
\hline $\mathrm{X} 3.4$ & 0,782 & 0,936 & 0 & Valid \\
\hline X3.5 & 0,871 & 0,946 & 0 & Valid \\
\hline X3.6 & 0,836 & 1,001 & 0 & Valid \\
\hline X3.7 & 0,926 & 0,879 & 0 & Valid \\
\hline $\mathrm{X} 3.8$ & 0,825 & 0,999 & 0 & Valid \\
\hline X3.9 & 0,663 & 0,715 & 0 & Valid \\
\hline
\end{tabular}

Sumber : Data primer diolah 
Dari tabel 7 di atas dapat dijelaskan secara keseluruhan bahwa faktor pendukung terhadap variabel Motivasi berpengaruh secara signifikan. Secara rinci dapat diuraikan bahwa dari setiap 1 (satu) satuan faktor pendukung memberikan pengaruh kepada variabel Motivasi sebesar nilai yang terdapat pada kolom standarized pada tabel 7 di atas. Yakni masing-masing faktor pada variabel Motivasi memliki pengaruh sebesar, kebutuhan sendiri dan keluarga (X2.1):0,701; Kebutuhan ibadah (X2.2):0,786; mengembangkan diri (X2.3): 0,823; penempatan karyawan sesuai kemampuan/keahlian(X2.4): 0,782; Kebutuhan partisipasi (X2.5):0,871; Adanya pengakuan (X2.6):0,836; Reward (X2.7) : 0,926; Hukuman (X2.8):0,825; dan Perasaan tenang karyawan (X2.9) : 0,663 .
Variabel Kinerja sebagai variabel endogen, dimana terdapat 2 (dua) variabel eksogen / bebas yang mempengaruhinya, yaitu: variabel Pembelajaran organisasi (X1), dan variabel Motivasi kerja karyawan (X2). Sebelum membahas pengaruh keduaya pada bagian selanjunya pada bab ini variabel Kinerja memiliki faktor pendorong yang membentuk variabel tersebut, yaitu: 1) Kualitas Hasil (Y1.1), 2) Kuantitas Hasil (Y1.2), 3) Ketepatan Waktu (Y1.3), 4) Sikap dan Perilaku karyawan (Y1.4); dan pengaruh keempat faktor pendorong / pembentuk variabel Kinerja karyawan tersebut dapat dijelaskan seperti pada Tabel 8 di bawah ini.

Tabel 8. Variabel Kinerja dan Faktor Pembentuknya

\begin{tabular}{lllll}
\hline Indikator & Standardize & Estimate & P & Keterangan \\
\hline Y1.1 & 0,889 & 1,474 & 0 & Valid \\
Y1.2 & 0,939 & 1,035 & 0 & Valid \\
Y1.3 & 0,920 & 1 & 0 & Valid \\
Y1.4 & 0,895 & 1,212 & 0 & Valid \\
\hline
\end{tabular}

Sumber : Data diolah

Faktor pendukung atau pembentuk variabel Kinerja menunjukkan bahwa faktor pembentuk variabel Kinerja signifikan dan valid serta berhubungan positif secara umum. Sedangkan secara rinci analisis statistiknya sebagai berikut: Kualitas Hasil (Y1.1) memiliki pengaruh terhadap variabel kinerja sebesar 0,889; kemudian faktor Kuantitas
Analisis pengaruh selanjutnya adalah pada tahap proses uji model persamaan, dimana variabel eksogen/ bebas pada model persamaan II ini atau model persamaan ini yaitu : Pembelajaran organisasi (X1), dan Motivasi Kerja (X2), sedangkan variabel endogen adalah Kinerja Karyawan (Y), ditunjukkan Tabel 9 di bawah ini:

Tabel 9. Hubungan Kausalitas pada Model Persamaan

\begin{tabular}{lccccc}
\hline $\begin{array}{c}\text { Variabel } \\
\text { Indipenden }\end{array}$ & $\begin{array}{c}\text { Variabel } \\
\text { Dependen }\end{array}$ & \multicolumn{2}{c}{ Koefisien Jalur Direct Effect } & Keterangan \\
& Estimate & Standarized & $p$-value & \\
\hline $\begin{array}{l}\text { Pembelajaran } \\
\text { Organisasi }\end{array}$ & Kinerja & 0,637 & 0,526 & 0,00 & Signifikan \\
Motivasi & Kinerja & 0,460 & 0,391 & 0,00 & Signifikan \\
\hline
\end{tabular}

Sumber : Data diolah

Analisis pengaruh variabel Pembelajaran organisasi sebagai variabel eksogen/bebas terhadap Kinerja Karyawan sebagai variabel endogen menunjukkan nilai pengaruh variabel Pembelajaran organisasi terhadap Kinerja Karyawan adalah sebesar 0,526 dengan tingkat $p$-value sebesar 0,00. Sehingga pengaruh yang ditimbulkan Pembelajaran organisasi terhadap Kinerja Karyawan bersifat positif 
dan signifikan, dengan nilai yang ditunjukkan oleh variabel Pembelajaran organisasi pada model persamaan menunjukkan variabel ini memiliki tingkat pengaruh lebih dibandingkan dengan variabel lainnya.Dalam mendukung temuan di lapangan pada penelitian ini seperti pada penelitian Yani Antariksa (2000) tentang pengaruh pelatihan terhadap kinerja karyawan PT. PAL Surabaya, yang menyimpulkan bahwa faktor yang membentuk prestasi kerja adalah program pelatihan yang tepat, waktu pelatihan, pengalaman, peralatan, dan komitmen untuk belajar. Bila penelitian ini dibandingkan dengan penelitian yang akan dilakukan adalah sama-sama mengkaji tentang pembelajaran, dimana varibel Pembelajaran Organisasi salah satu dari tiga variabel yang diteliti dalam penelitian ini.

Variabel motivasi pada model persamaan menunjukkan nilai pengaruh variabel ini terhadap variabel endogen (variabel Kinerja karyawan) sebesar 0,391 dengan tingkat $p$-value sebesar 0,00 sehingga dapat dikatakan bahwa pengaruh variabel Motivasi kerja terhadap variabel Kinerja karyawan bersifat positif dan signifikan. Seperti halnya yang ditunjukkan oleh variabel Pembelajaran organisasi di atas.

Hal ini merujuk pada penelitian yang dilakukan oleh Fauziah Salleh et.al.,(2011) penelitian tersebut dimuat dalam Journal of Business and Social Sciences Vol.4 No.1, 4th April 2011. Dalam sebuah tulisan berjudul "The Effect of Motivation on Job Performance of State Government Employees in Malaysia", yang meneliti tentang pengaruh motivasi terhadap kinerja 50 orang pegawai pemerintahan di tiga negara bagian pesisir timur Malaysia sebagai sampel. Dalam penelitian tersebut menunjukkan bahwa motivasi berafiliasi atau bekerjasama yang berhubungan atau berpengaruh positif terhadap kinerja pegawai, dimana hal ini mengindikasikan bahwa para pegawai pemerintah yang memiliki motivasi berafiliasi seperti menyepakati atau memahami perasaan dan pendapat rekan atau bawahannya selanjutnya akan bekerja keras untuk kesepakatan atau persetujuan dari bawahan dan rekan (Boyatzis, 1972). Penelitian ini menunjukkan bahwa orang yang memiliki motivasi berafiliasi yang tinggi besar kemungkinan menjadi pegawai yang sempurna (www.ijbssnet.com).

Setelah membahas pengaruh variabel eksogen/ bebas yakni : Pembelajaran organisasi (X1), dan Motivasi (X2) terhadap variabel eksogen/terikat yaitu Kinerja (Y), dapat diambil kesimpulan dalam bentuk model persamaan $Y=1 X 1+2 X 2$ dan $Y=0,526 X 1$ $+0,391 \mathrm{X} 2$. Dari persamaan tersebut hubungan pengaruh antara variabel bebas (Pembelajaran organisasi dan Motivasi kerja) ditunjukkan dalam bentuk angka secara positif dan signifikan mempengaruhi variabel terikatnya (Kinerja karyawan) pada penelitian ini. Sehingga keseluruhan variabel bebas dalam penelitian ini dapat dikatakan sebagai variabel utama yang mampu memberikan kontribusi yang cukup besar terhadap Kinerja karyawan pada Koperasi Syariah (BMT) di Malang Raya.

Interpretasi persamaan kedua ini dapat diuraikan, pertama bahwa pengaruh variabel Pembelajaran organisasi berpengaruh terhadap Kinerja karyawan sebesar 0,526 yang berarti bahwa setiap tidakan ataupun kegiatan dalam Koperasi Syariah (BMT) yang diteliti memberikan kontribusi terhadap Kinerja karyawan sebesar nilai perngaruh tersebut. Kedua, kontribusi pengaruh variabel Motivasi kerja karyawan dalam setiap aktivitas kerja Koperasi Syariah (BMT) terhadap Kinerja karyawan sebesar 0,2941 pada penelitian ini dengan sampel 118 orang karyawan pada Koperasi Syariah (BMT) di Malang Raya. Dari hasil penghitungan statistik menggunakan program software komputer AMOS 4.0 menunjukkan bahwa pada persamaan ini variabel Pembelajaran organisasi memberikan kontribusi lebih dibandingkan variabel bebas lainnya. Sehingga dapat dikatakan bahwa variabel Pembelajaran organisasi memiliki pengaruh yang lebih kuat dalam proses peningkatan Kinerja karyawan Koperasi Syariah (BMT) di Malang Raya.

\section{SIMPULAN DAN SARAN}

Berdasarkan haasil analisis penelitian pada bagian terdahulu, maka dapat dikemukakan beberapa simpulan sebagai berikut :

Pembelajaran organisasi berpengaruh positif dan signifikan terhadap kinerja karyawan Koperasi Syariah (BMT) di Malang Raya. Hasil yang didapat pada penelitian ini menunjukkan bahwa pembelajaran organisasi dengan jalan; pendidikan dan pelatihan, mentoring pembimbingan, dan pengalaman di lapangan memberikan kontribusi terhadap peningkatan kinerja karyawan yang melingkupi; kualitas hasil, kuantitas hasil, ketepatran waktu, sikap, dan perilaku karyawan Koperasi Syariah (BMT) di Malang Raya.

Kemudian Motivasi karyawan berpengaruh positif dan signifikan terhadap kinerja karyawan Koperasi Syariah (BMT) di Malang Raya. Dari penelitian ini menunjukkan bahwa motivasi kerja karyawan antara lain : kebutuhan sendiri dan keluarga, kebutuhan ibadah, mengembangkan diri, 
menempatkan karyawan sesuai kemampuan, kebutuhan partisipasi kelompok, kebutuhan pengakuan, reward, hukuman, dan perasaan aman dan tenang memberikan kontribusi positif terhadap peningkatan kinerja karyawan yaitu meliputi: kualitas hasil, kuantitas hasil, ketepatan waktu, sikap, dan perilaku karyawan Koperasi Syariah (BMT) di Malang Raya. Maka pada model persamaan II (nomor 3,4, dan 5) menunjukkan pengaruh positif dan signifikan antara variabel bebas dan terikat yang diteliti dalam penelitian ini membuktikan bahwa model persamaan II dapat terpenuhi.

\section{DAFTAR PUSTAKA}

Agung, I Gusti Ngurah, 1992, Metode Penelitian Sosial, Jakarta, Penerbit PT. Gramedia Pustaka Utama.

Al Bukhari, Imam, 1981, Shahih Bukhari, Beirut Libanon : Daar al-Fikr.

Al Garni, Aidh, 2006, Memahami Semangat Zaman, Kunci Sukses Kaum Beriman, Jakarta, Ikrar Mandiri Abadi.

Alma, Buchari, 2009, Kewirausahaan, Edisi Revisi, Bandung, Penerbit Alfabeta.

Amin, Riawan, 2007. Zikir, Pikir, Mikir. The Celestial Management, Jakarta, Penerbit Senayan Abadi Publising.

Amstrong, Michael 1998. Manajemen Sumber Daya Manusia, Ahli Bahasa Hadyana Pujatmaja, Jakarta, Penerbit PT Elex Media Komputindo.

Ang Michael, 1995, Menjadi Manajer yang Lebih Baik Lagi, Edisi Terjemahan, Jakarta, Penerbit Binarupa Aksara.

Ang Michael, 1998. Manajemen Sumber Daya Manusia, Alih bahasa Hadyana Pujaatmaja, Jakarta, Penerbit PT. Elex Media Komputindo.

Anoraga, Panji, Ninik Widiyanti, 2007, Dinamika Koperasi, Jakarta, Penerbit P.T. Rineka Cipta.

Anwar, Syaifuddin, 2004, Reliabilitas dan Validitas, Yogyakarta, Pustaka Pelajar.

Ar Rusyidi, Noerchozin, 2008, Menggali Nilai-nilai Islami, Yogyakarta, Sabda Media Group.

Arbuckle, James L. Wonthke Werner. 1999. Amos 4.0 User's Guide. Chicago: Small Waters Corporation
Arikunto. Suharsimi, 1997, Prosedur Penelitian Suatu Pendekatan Praktek, Yogyakarta, Edisi Revisi, Penerbit Rineka Cipta.

Ary, d.S dan Jacobz, LC .1985, Introduction to Research in Educations .New York, Halt Rinechurt \& Winston.

Atiriette, Cecil V.2002. Learning Organization and Leadership Style an Applied. 